\title{
Acupuncture induced pneumothorax - a case report
}

\author{
Sanjeev Tandon, K.B. Gupta
}

\begin{abstract}
Abstrak
Penggunaan akupunktur sebagai salah satu alternatifpengobatan semakin populer. Namun cara ini tidak sepenuhnya bebas dari komplikasi. Dalam tulisan ini dilaporkan kasus pneumotorak yang terjadi setelah prosedur akupunktur pada seorang laki-laki usia 48 tahun yang menderita asma bronkial.
\end{abstract}

\begin{abstract}
Acupuncture is now becoming increasingly popular as a therapeutic modality, however its use is not devoid of complications. A case of pneumothorax following acupuncture in a 48-year-old male suffering from bronchial asthma is being reported.
\end{abstract}

Keywords: acupuncture, pneumothorax, iatrogenic

\section{INTRODUCTION}

Acupuncture is in vogue as a therapeutic measure for a variety of ailments including bronchial asthma, especially in cases where a conventional treatment has failed. ${ }^{1}$ However, the insertion of needles in the chest wall or at the base of the neck is not devoid of complications. ${ }^{2}$ A case of life threatening pneumothorax following acupuncture of the chest wall in a patient suffering from bronchial asthma is being reported.

\section{CASE REPORT}

A 48-year-old male consulted an acupuncturist for treatment of bronchial asthma, which he had since the age of 13 years, when regular treatment with bronchodilators and corticosteroids became less effective. Two needles were inserted into the anterior chest wall, in the right third and fifth intercostal spaces parasternally and stimulated electrically. Over the next 24 hours, the patient developed severe chest pain on the right side and progressively increasing breathlessness. He was referred to the emergency room where he was found to be pale, dyspneic. The breath sounds were absent over the right hemithorax. Clinical examination suggested a right pneumothorax and chest radiography confirmed the same (Fig.1). An intercostal catheter with under water seal was inserted in the right fifth

Department of Chest and Tuberculosis, Pt. B.D. Sharma Post Graduate institute of Medical Sciences, Rohtak - 12400I, Haryana, India intercostal space. The lung expanded fully, the chest tube was removed within 72 hours and the patient discharged.

\section{DISCUSSION}

Acupuncture is performed by the insertion of fine needles at specific sites on the body surface followed by mechanical or electrical stimulations (electroacupuncture). ${ }^{3}$ Traditionally, several points on the chest wall and base of the neck are used for the treatment of asthma.

Acupuncture on the chest wall may cause pneumothorax, either by perforation of the pleura which may allow an inflow of air through the fistulous needle track (pleuro cutaneous fistula) or the needle can puncture the lung. Delayed pneumothorax is a common mode of presentation in such cases as is evident in the present case, since the entry of air through a fine needle track may be slow. Hence sometimes immediate chest radiography after the procedure may not show any evidence of pneumothorax, but it may become evident some hours later.

In the last few years sporadic reports about pneumothorax complicating acupuncture of chest and shoulder regions have appeared. ${ }^{4-7}$ However only in three of these cases was acupuncture done to treat bronchial asthma. ${ }^{8-9}$ In spite of favourable reports, ${ }^{10}$ the benefit of acupuncture as a form of treatment for chronic bronchial asthma is still controversial ${ }^{11}$ and its dangers when done on the chest wall are clearly il- 


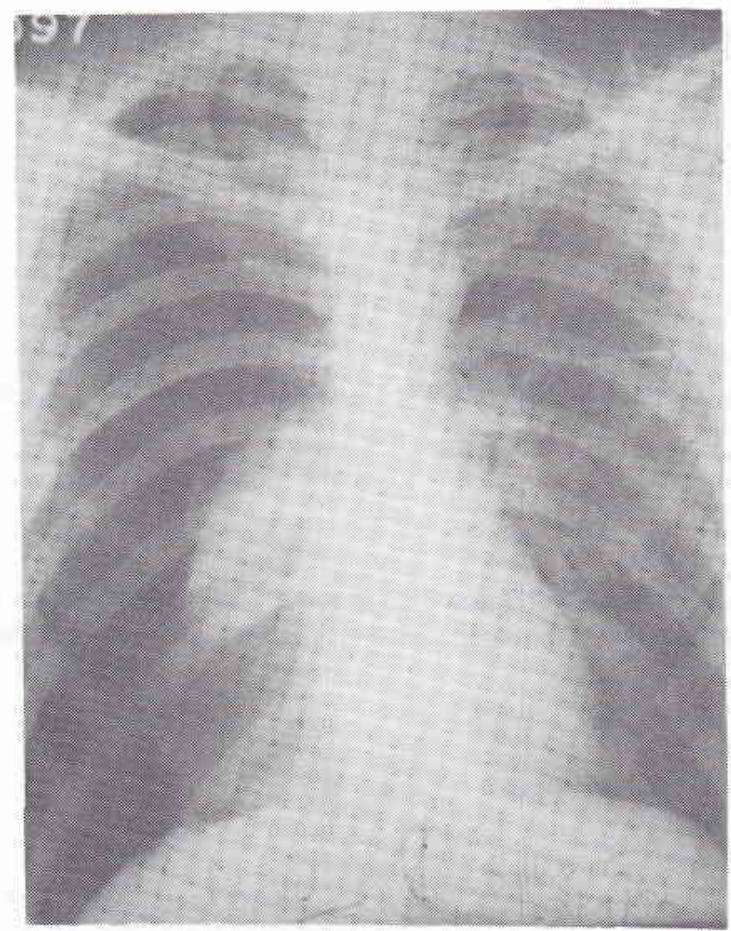

Figure I. Skiagram chest showing right sided pneumothorax

lustrated in this case. Hence, the physician should be aware of the possible risks and complications of this technique. Patients in whom pleural trauma is suspected during acupuncture should undergo immediate and repeat chest radiography after 12 to 24 hours to exclude pneumothorax and treated accordingly.

\section{REFERENCES}

1. Takishima T, Mue S, Tamura G, Ishihara T, Watanabe K. Bronchodilating effects of acupuncture in patients with acute asthma. Ann Allerg 1982;48:44-6.

2. Carron H, Epstein BS, Grand B. Complications of acupuncture. JAMA 1974;228:1552-5.

3. Millman BS. Acupuncture: context and critique. Ann Rev Med 1977;28:223-7.

4. Goldberg I. Pneumothorax associated with acupuncture. Med J Aust 1973;1:941-3.
5. Gorbett M, Sinclair M. Acu- and pleurapuncture (letter). New Engl J Med 1974;290:167-8.

6. Stack BHR. Pneumothorax associated with acupuncture (letter). Br. Med J 1978;1:96.

7. Mazal DA, King T, Harvey J, Cohen J. Bilateral pneumothorax after acupuncture (letter). New Eng J Med 1980;302:1365.

8. Ritter HG, Tarala R. Pneumothorax after acupuncture. Br Med J 1978;2:602-3.

9. Bonder G, Topilsky M, Greif J. Pneumothorax as a complication of acupuncture in the treatment of bronchial asthma. Ann Allergy 1983;51:401-2.

10. Tashkin PD, Bresler ED, Kroenig JR, Kerschner H, Katz LR, Coulson A. Comparison of real and stimulated acupuncture and isoproterenol in metacholine induced asthma. Ann Allerg 1977;39:379-81.

11. Rosenthal RR, Wang KP, Norma PS. All that is asthma does not wheeze. New Eng J Med 1975;292:372-5. 